\title{
Syntheses, Characterization and In-Vitro Anti-Inflammatory Activity of Some Novel Thiophenes
}

Satyendra Deka ${ }^{*}$, Shamanna Mohan ${ }^{2}$, Janardhan Saravanan ${ }^{2}$, Manoj Kakati², Apurba Talukdar ${ }^{1}$, Bhargab Jyoti Sahariah ${ }^{1}$, Biplab KumarDey ${ }^{1}$, Rama Kanta Sarma ${ }^{3}$

${ }^{1}$ Assam Down Town University, Dept. of Pharmacy, Panikhati, Guwahati-26, Assam, India; ${ }^{2}$ Department of Pharmaceutical Chemistry, P.E.S. College of Pharmacy, Bangalore-50, Karnataka, India; ${ }^{3}$ Govt. Ayurvedic College, Dept. of RS \& VK Guwahati-14, Assam, India

\begin{abstract}
Citation: Deka S, Mohan S, Saravanan J, Kakat M, Talukdar A, Sahariah BJ, Dey BK, Sarma RK. Syntheses, Characterization and In-Vitro AntiInflammatory Activity of Some Novel Thiophenes. Maced J Med Sci 2012 Jul 31; 5(2):159-163. Maced J Med Sci. 2012 Jul 31; 5(2):159-163. 5773.2012 .0225

Key words: Thiophenes; Gewald reaction; in vitro anti-inflammatory activity; Denaturation; Microwave.

Correspondence: Mr. Satyendra Deka. Assam Down Town University, Department of Pharmacy, Gandhi Nagar, Panikhaiti, Dist. Kamrup, Guwahati Assam 781026, India. Phone: 00919706602852 E-Mail: harekrishnaks@yahoo.com

Received: 23-Jan-2012; Accepted: 28-Apr-2012; Online first: 12-Jun-2012

Copyright: (c) 2012 Deka S. This is an open access article distributed under the terms of the Creative Comm Ase, distribution, and reproduction in any medium, provided the original author and source are credited.

Competing Interests: The authors have declared that no competing interests exist.
\end{abstract}

\section{Abstract}

Aim: The present study was aimed to synthesize a series of 2-substituted benzylidine imino-3-(3-chloro4-fluorophenyl)-carboxamido-4,5-trimethylene thiophenes SPJ-1(a-m) and to evaluate their in-vitro anti-inflammatory activity.

Materials and Methods: The starting material (SPJ-1) was prepared by the application of versatile Gewald reaction. The In-vitro anti-inflammatory activity of synthesized compounds [SPJ-1(a-m)] was evaluated using inhibition of bovine serum albumin denaturation method.

Result: SPJ-1b and SPJ-1g have shown significant in-vitro anti-inflammatory activity.

Conclusion: The findings of the present study clearly demonstrate that chloro functional group possess inhibition of bovine serum albumin denaturation capacity and has in-vitro anti-inflammatory activity. However hydroxyl, nitro, methyl, methoxy and dimethyl amino derivatives did not show any in-vitro antiinflammatory activity.

\section{Introduction}

Thiophene containing organic compounds forms a significant group of drugs which exhibit an array of biological activities ranging from anti-inflammatory [1-5], antibacterial, antifungal, local anaesthetic, analgesic, anti-neoplastic, antiarthritic, antitussive and so on.

The starting material 2-amino-3-(3-chloro-4fluoro phenyl carboxamido)-4,5-trimethylene thiophene (SPJ-1) was prepared by the application of the versatile
Gewald reaction $[6,7]$. Treatment of starting material with various substituted aromatic aldehydes gave the title compounds SPJ-1(a-m).

All the synthesized compounds were characterized by their physical and spectral data. The IR spectra of compound SPJ-1 showed an intense sharp $\mathrm{NH}_{2}$ absorption peak at $3413.29 \mathrm{~cm}^{-2}$; C-S peak at $778.75 \mathrm{~cm}^{-2}$. The formation of Schiff's bases SPJ-1(a-m) was confirmed by the presence of an imine $(\mathrm{HC}=\mathrm{N})$ 
peak at 1659.74- $1643.67 \mathrm{~cm}^{-1}$ and the absence of $\mathrm{NH}_{2}$ peak which was present in the IR spectra of SPJ-1. The ${ }^{1} \mathrm{NMR}$ spectra of compound SPJ-1a, SPJ-1e, SPJ-1i exhibited all the expected protons. Mass spectra of compound SPJ-1-d exhibited $\mathrm{M}^{+}$ion peak at 428 (16.94\%) indicating that this molecule is rather unstable at $70 \mathrm{eV}$ and undergo fragmentation to form daughter ions. Appearance of $\mathrm{M}^{+}$ion and their characteristic daughter ions confirm the structure proposed for the compounds.

\section{Materials and Methods}

\section{Drugs and Chemicals}

Ethylcyanoacetate (Sisco Research Laboratories Pvt. Ltd., India), Cyclopentanone (Sisco Research Laboratories Pvt. Ltd., India), Sulphur (SD Fine Chem,India), Bovine serum albumin (Merck Limited). The Standard Ibuprofen, solvents and other chemical used for the study were of analytical grade and purchased from local firms.

\section{Experimental design}

Experimental design is been given in Figure 1 and Figure 2.
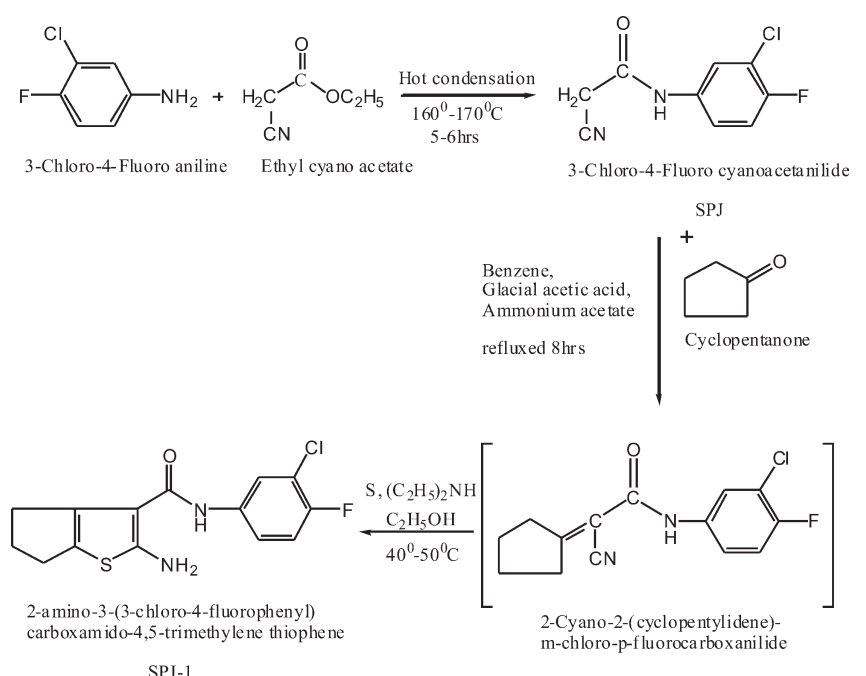

Figure 1: Synthesis of 2-amino-3-(3-chloro-4-fluorophenyl) carboxamido-4,5-trimethylene thiophene (SPJ-1).

\section{Procedure}

At first 3-Chloro-4-fluoro cyanoacetanilide was prepared by hot condensation of 3-chloro-4-fluoro aniline and ethyl cyanoacetate. The appropriate thiophene 2-

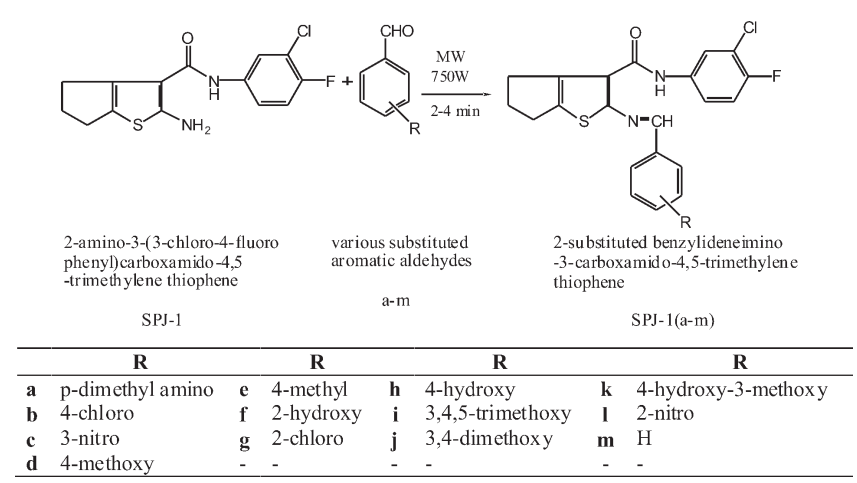

Figure 2: Syntheses of 2-substituted benzylidene imino-3-(3-chloro-4fluorophenyl) carboxamido-4,5-trimethylene thiophenes. SPJ-1(a-m).

amino-3-(3-chloro-4-fluorophenyl) carboxamido-4,5trimethylene thiophene (SPJ-1) was prepared by Gewald reaction [6, 7]; between cyclopentanone and 3-Chloro4-fluoro cyanoacetanilide through the production of an intermediate 2-Cyano-2-(cyclopentylidene)-m-chloropfluoro carboxanilide and further treatment of intermediate with sulphur in presence of ethanol and diethylamine.

Step 1- Synthesis of 3-Chloro-4-fluoro cyanoacetanilide (SPJ). A mixture of 3-chloro-4-fluoro aniline $(0.5 \mathrm{M}, 36.35 \mathrm{gm})$ and Ethyl cyanoacetate $(0.5 \mathrm{M}$, $26.60 \mathrm{ml}$ ) was heated at $160^{\circ}-170^{\circ} \mathrm{C}$ for 6 hours. The reaction mixture was left at room temperature overnight. The solid obtained was washed with ethanol, dried and then recrystallized from acetone water mixture (5:1 ratio). Yield: $55.70 \%$. M.P. $172{ }^{\circ} \mathrm{C}$.

Step 2- Synthesis of 2-amino-3-(3-chloro-4fluorophenyl) carboxamido-4,5-trimethylene thiophene (SPJ-1). A mixture of 3-Chloro-4-fluoro cyanoacetanilide SPJ (8.48 gm, $0.04 \mathrm{M}$ ), cyclopentanone (3.45 ml, 0.04 $\mathrm{M})$, ammonium acetate (2 gm) and glacial acetic acid (2 $\mathrm{ml})$ in benzene $(150 \mathrm{ml})$ was refluxed for $8 \mathrm{hrs}$ using Dean stark apparatus with an arrangement for continuous separation of water. After $8 \mathrm{hrs}$, the reaction mixture was cooled, diluted with $20 \mathrm{ml}$ of benzene and washed 3 times with sodium carbonate solution (10\% w/v in water) and water successively. The solvent was removed under vacuum and the intermediate crude product 2-Cyano-2(cyclopentylidene)-m-chloro-p-fluorocarboxanilide obtained was immediately processed for the next step.

A mixture of 2-Cyano-2-(cyclopentylidene)-3chloro-4-fluorocarboxanilide, Sulphur (1.28 gm, 0.04 $\mathrm{Mol})$ and ethanol $(30 \mathrm{ml})$ was taken in conical flask. The above mixture was stirred at $45-50^{\circ} \mathrm{C}$. Once the 
Deka et al. Syntheses, Characterization and In-Vitro Anti-Inflammatory Activity of Some Novel Thiophenes

temperature was attained, Diethyl amine $(4 \mathrm{ml})$ was added drop wise until Sulphur completely went in. The solid obtained was filtered, washed with ethanol and recrystallized from benzene. Yield: $95.75 \%$. M.P.: 122 ${ }^{\circ} \mathrm{C}, \mathrm{IR}(\mathrm{KBr})$ : $3413.29\left(-\mathrm{NH}_{2}\right) ; 3329.98$ (-NH str); 3079.82 (Ar-CH str); 2918.98 (Ali-CH); 1633.73 (-NH bend); 1658.33 (C=O); 1508.31 (Ar C=C); $1221.34(\mathrm{C}-\mathrm{F}) ; 828.40$ (C-N); 778.75 (C-S); 688.31 (C-Cl).

Step 3- General method for the syntheses of 2substituted benzylidene imino-3-(3-chloro-4fluorophenyl) carboxamido-4,5-trimethylene thiophenes. SPJ-1(a-m). A mixture of the starting compound (SPJ-1) $(0.005 \mathrm{Mol})$ and the required aryl aldehydes (a-m) $(0.005$ $\mathrm{Mol})$ in isopropyl alcohol (10 ml) and catalytic amount of glacial acetic acid $(2 \mathrm{ml})$ was subjected to Microwave irradiation [8]; at 750W for 2-4 minutes. Then cooled to room temperature. The solid separated was filtered, washed with isopropyl alcohol and recrystallized with DMF: Ethanol (6:1 ratio).

\section{In-vitro Anti-inflammatory activity}

The synthesized compounds were screened for in-vitro anti-inflammatory activity by inhibition of bovine serum albumin denaturation method according to M.N.A. Rao et al [9].

\section{Experimental design}

The test compounds were dissolved in minimum amount of dimethyl formamide (DMF) and diluted with phosphate buffer (0.2 M, pH 7.4). Final concentration of DMF in all solution was less than $2.5 \%$. Test solution (1 $\mathrm{ml}$ ) containing different concentrations of drug was mixed with $1 \mathrm{ml}$ of $1 \mathrm{mM}$ albumin solution in phosphate buffer and incubated at $27^{\circ} \pm 1^{\circ} \mathrm{C}$ for $15 \mathrm{~min}$. Denaturation was induced by keeping the reaction mixture at $60^{\circ} \pm 1^{\circ} \mathrm{C}$ in a water bath for $10 \mathrm{~min}$. After cooling the turbidity was measured at $660 \mathrm{~nm}$ (Shimadzu Spectrometer). Percentage inhibition of denaturation was calculated from control where no drug was added. Each experiment was done in triplicate and the average was taken. The percentage of inhibition is calculated from the following formula.

The standard solution was also prepared as similar to that of the test solution. Ibuprofen was used as a standard.

$\%$ Inhibition = $100(1-\mathrm{Vt} / \mathrm{Vc})$

Where, $\mathrm{Vt}=$ Drug absorbance of triplicate average, $\mathrm{Vc}=$ Control absorbance of triplicate average.

\section{Results}

\section{Physical data}

Melting points were determined in open capillaries and are uncorrected. Purity of the compounds was checked by TLC on silica gel plates. The solvent system used to carry out the TLC is Benzene : Chloroform at a ratio of $7: 3$.

\section{Spectral data}

IR spectra $\left(\mathrm{cm}^{-2}\right)$ were recorded in $\mathrm{KBr}$ on a Shimadzu FTIR-8700 spectrometer.HNMR (ppm) [NMR $\left.\left(\mathrm{CDCl}_{3}\right) \delta(\mathrm{ppm})\right]$ in $\mathrm{CDCl}_{3}$ using TMS as reference on Bruker 400 AMX. Mass spectra of the compound coded SPJ-1-d was carried out.

IR (KBr) cm-2: SPJ-1 (a-m): (3335.82-3200.25) NH str; (3086.77-3051.69) Ar-C-H; (2949.76-2915.01) Ali-C-H; (1680.03-1663.60) C=O; (1635.58-1600.57) NH bend; (1524.65-1489.83) Ar-C=C; (1643.67-1659.74) $\mathrm{HC}=\mathrm{N}$; (1222.14-1207.15) C-F; (827.19-811.08) C-N; 756.81-733.74 (C-S); (721.85-669.35) C-Cl;(2964.232959.13) $\mathrm{CH}$ of $\mathrm{CH}_{3}$; (1381.34-1350.12) N-O of $\mathrm{NO}_{2}$; (3453.90-3449.46) broad peak of $\mathrm{OH}$.

Compound SPJ-1-a: 11.45 (s, 1H, NH); 8.28 (s, $1 \mathrm{H}, \mathrm{N}=\mathrm{CH}) ; 2.85\left(\mathrm{~s}, 6 \mathrm{H}, \mathrm{CH}_{3}\right) ; 3.20\left(\mathrm{t}, 2 \mathrm{H}, \mathrm{CH}_{2}\right.$, cyclopentane); 2.15 ( $\mathrm{m}, 2 \mathrm{H}, \mathrm{CH}_{2}$, cyclopentane); 2.55 (t, 2H, $\mathrm{CH}_{2}$, cyclopentane); 7.50 (d, $\left.1 \mathrm{H}, \mathrm{Ar}-\mathrm{CH}\right) ; 7.12$ (d, $1 \mathrm{H}, \mathrm{Ar}-\mathrm{CH}) ; 7.98$ (d, 1H, Ar- CH); 7.72 (d, 1H, Ar-CH); $7.72(\mathrm{~d}, 1 \mathrm{H}, \mathrm{Ar}-\mathrm{CH}) ; 6.75$ (d, 1H, Ar-CH ); 6.75 (d, 1H, Ar-CH).

Compound SPJ-1-e: 11.19 (s, 1H, NH); 8.43 $(\mathrm{s}, 1 \mathrm{H}, \mathrm{N}=\mathrm{CH}) ; 2.46\left(\mathrm{~s}, 3 \mathrm{H}, \mathrm{CH}_{3}\right) ; 3.13\left(\mathrm{t}, 2 \mathrm{H}, \mathrm{CH}_{2}\right.$, cyclopentane); 2.42 (m, $2 \mathrm{H}, \mathrm{CH}_{2}$, cyclopentane); 2.90 (t, $2 \mathrm{H}, \mathrm{CH}_{2}$, cyclopentane); 7.50 (d, $\left.1 \mathrm{H}, \mathrm{Ar}-\mathrm{CH}\right) ; 7.12$ (d, $1 \mathrm{H}, \mathrm{Ar}-\mathrm{CH}) ; 7.94$ (d, 1H, Ar-CH ); 7.76 (d, 1H, Ar-CH); $7.76(\mathrm{~d}, 1 \mathrm{H}, \mathrm{Ar}-\mathrm{CH}) ; 7.38$ (d, 1H, Ar-CH); 7.38 (d, 1H, Ar$\mathrm{CH})$.

Table 1: Physical data of compounds prepared.

\begin{tabular}{|c|c|c|c|c|c|}
\hline Compounds & Molecular formula & $\begin{array}{l}\text { M.W. } \\
\text { (gm) }\end{array}$ & $\begin{array}{l}\text { M.P. } \\
\left({ }^{\circ} \mathrm{C}\right)\end{array}$ & $R_{f}$ Value & $\begin{array}{c}\text { Yield } \\
(\%)\end{array}$ \\
\hline SPJ-1 & $\mathrm{C}_{14} \mathrm{H}_{12} \mathrm{~N}_{2} \mathrm{OSClF}$ & 310 & 122 & 0.81 & 94.87 \\
\hline SPJ-1-a & $\mathrm{C}_{23} \mathrm{H}_{21} \mathrm{~N}_{3} \mathrm{OSClF}$ & 441 & 219 & 0.90 & 73.11 \\
\hline SPJ-1-b & $\mathrm{C}_{21} \mathrm{H}_{15} \mathrm{~N}_{2} \mathrm{OSCl} \mathrm{l}_{2} \mathrm{~F}$ & 432 & 195 & 0.79 & 71.23 \\
\hline SPJ-1-C & $\mathrm{C}_{21} \mathrm{H}_{15} \mathrm{~N}_{3} \mathrm{O}_{3} \mathrm{SClF}$ & 431 & 186 & 0.80 & 67.42 \\
\hline SPJ-1-d & $\mathrm{C}_{22} \mathrm{H}_{18} \mathrm{~N}_{2} \mathrm{O}_{2} \mathrm{SClF}$ & 428 & 178 & 0.86 & 72.28 \\
\hline SPJ-1-e & $\mathrm{C}_{22} \mathrm{H}_{18} \mathrm{~N}_{2} \mathrm{OS} \mathrm{ClF}$ & 412 & 195 & 0.76 & 65.34 \\
\hline SPJ-1-f & $\mathrm{C}_{21} \mathrm{H}_{16} \mathrm{~N}_{2} \mathrm{O}_{2}$ SCIF & 414 & 245 & 0.78 & 62.65 \\
\hline SPJ-1-g & $\mathrm{C}_{21} \mathrm{H}_{15} \mathrm{~N}_{2} \mathrm{OSCl} l_{2} \mathrm{~F}$ & 432 & 192 & 0.93 & 74.34 \\
\hline SPJ-1-h & $\mathrm{C}_{21} \mathrm{H}_{16} \mathrm{~N}_{2} \mathrm{O}_{2}$ SCIF & 414 & 214 & 0.79 & 65.81 \\
\hline SPJ-1-i & $\mathrm{C}_{24} \mathrm{H}_{22} \mathrm{~N}_{2} \mathrm{O}_{4}$ SCIF & 490 & 222 & 0.94 & 68.56 \\
\hline SPJ-1-j & $\mathrm{C}_{23} \mathrm{H}_{21} \mathrm{~N}_{2} \mathrm{O}_{3} \mathrm{SClF}$ & 459 & 195 & 0.88 & 70.34 \\
\hline SPJ-1-k & $\mathrm{C}_{22} \mathrm{H}_{19} \mathrm{~N}_{2} \mathrm{O}_{3} \mathrm{SClF}$ & 445 & 234 & 0.74 & 58.56 \\
\hline SPJ-1-I & $\mathrm{C}_{21} \mathrm{H}_{15} \mathrm{~N}_{3} \mathrm{O}_{3} \mathrm{SClF}$ & 431 & 180 & 0.91 & 59.42 \\
\hline SPJ-1-m & $\mathrm{C}_{21} \mathrm{H}_{15} \mathrm{~N}_{2} \mathrm{OSCIF}$ & 397 & 178 & 0.84 & 66.82 \\
\hline
\end{tabular}


Compound SPJ-1-i: 11.06 (s, 1H, NH); 8.40 (s, $1 \mathrm{H}, \mathrm{N}=\mathrm{CH}) ; 3.12\left(\mathrm{t}, 2 \mathrm{H}, \mathrm{CH}_{2}\right.$, cyclopentane); $2.43(\mathrm{~m}$, $2 \mathrm{H}, \mathrm{CH}_{2}$, cyclopentane); 2.92 (t, $2 \mathrm{H}, \mathrm{CH}_{2}$, cyclopentane); $7.81(\mathrm{~d}, 1 \mathrm{H}, \mathrm{CH}) ; 7.45(\mathrm{~d}, 1 \mathrm{H}, \mathrm{CH}) ; 7.92(\mathrm{~d}, 1 \mathrm{H}, \mathrm{CH}) ; 7.12$ (s, 1H, CH); $7.12(\mathrm{~s}, 1 \mathrm{H}, \mathrm{CH}) ; 3.95\left(\mathrm{~s}, 9 \mathrm{H}, \mathrm{OCH}_{3}\right)$.

Table 2: In-vitro Anti-inflammatory activity data.

\begin{tabular}{cccccc}
\hline $\begin{array}{c}\text { COMP. } \\
\text { CODE }\end{array}$ & $\mathbf{R}$ & $\begin{array}{c}\text { In vitro \% } \\
\text { Inhibition }\end{array}$ & $\begin{array}{c}\text { COMP. } \\
\text { CODE }\end{array}$ & $\mathbf{R}$ & $\begin{array}{c}\text { In vitro \% } \\
\text { Inhibition }\end{array}$ \\
\hline SPJ-1-a & $4-\mathrm{N}\left(\mathrm{CH}_{3}\right)_{2}$ & 39 & $\mathrm{SPJ}-1-\mathrm{h}$ & $4-\mathrm{OH}$ & 51 \\
SPJ-1-b & $4-\mathrm{Cl}$ & $\mathbf{6 1}$ & $\mathrm{SPJ}-1-\mathrm{i}$ & $3,4,5-\left(\mathrm{OCH}_{3}\right)_{3}$ & 46 \\
SPJ-1-C & $3-\mathrm{NO}_{2}$ & 48 & SPJ-1-j & $3,4-\left(\mathrm{OCH}_{3}\right)_{2}$ & 52 \\
SPJ-1-d & $4-\mathrm{OCH}_{3}$ & 37 & SPJ-1-k & $4-\mathrm{OH}-3-\mathrm{OCH}_{3}$ & 50 \\
SPJ-1-e & $4-\mathrm{CH}_{3}$ & 41 & SPJ-1-I & $2-\mathrm{NO}_{2}$ & 49 \\
SPJ-1-f & $2-\mathrm{OH}$ & 53 & SPJ-1-m & $-\mathrm{H}$ & 32 \\
SPJ-1-g & $\mathbf{2 - C l}$ & $\mathbf{6 5}$ & Ibuprofen & ------- & $\mathbf{8 2}$ \\
\hline
\end{tabular}

\section{In-vitro Anti-inflammatory activity data}

Among all the compounds tested, SPJ-1g with 2'-chloro substitution and SPJ-1b with 4'-chloro substitution showed good in-vitro anti-inflammatory activity (65\% and 61\%). The remaining compounds exhibited mild to moderate activities (32\% to 53\%) compared to the standard Ibuprofen (82\%).

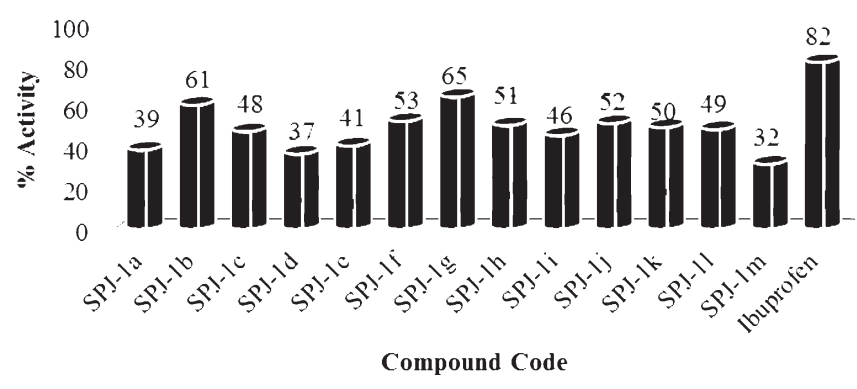

Figure 3: Graphical representation of in-vitro Anti-inflammatory activity data.

\section{Discussion}

The purpose of the present work was to synthesize a series of desired title compounds (SPJ-1a-m) from 2-amino-3-(3-chloro-4-fluorophenyl) carboxamido-4, 5-trimethylene thiophene (SPJ-1) by reacting with various substituted aromatic aldehydes (a $\mathrm{m})$. The syntheses were carried out in accordance with the literature as in the Figure 1 and 2.

As discussed earlier, thiophenes are a class of heterocyclic compounds that shows an array of biological activities which include anti-inflammatory, anti-bacterial, anti-fungal, anti-tubercular, anti-convulsant, anti-cancer, and local anesthetic activity.
The presence of fluorine on a bioactive molecule enhances cell penetration and protein binding. Thus it was felt worthwhile to take up the present investigation to synthesize some novel thiophenes and test their effect on in-vitro anti-inflammatory activity.

Clinically established anti-inflammatory drugs have shown to inhibit heat coagulation of proteins. These anti-inflammatory drugs have exerted an inhibitory activity on immune haemolysis and also have suppressive effect on vascular reactivity. Denaturation as one of the causes of inflammation is well documented. Antiinflammatory drugs interact in some way with proteins. To cause the interaction between the drug and the proteins, the stability of proteins against heat coagulation can be measured.

\section{Protein Denaturation}

All proteins begin their existence on a ribosome as a linear sequence of amino acid residues. This polypeptide must fold during and following synthesis to take up its native conformation. We have seen that a native protein conformation is only marginally stable. Modest changes in the protein's environment can bring about structural changes that can affect function.

\section{Loss of Protein Structure Results in Loss of Function}

Protein structures have evolved to function in particular cellular environments. Conditions different from those in the cell can result in protein structural changes, large and small. A loss of three-dimensional structure sufficient to cause loss of function is called denaturation.

The in-vitro anti-inflammatory activity [10]; was carried out using inhibition of bovine serum albumin denaturation method according to M.N.A. Rao et al. All the compounds (SPJ-1-a-m) were screened for in-vitro anti-inflammatory activity. The results are shown in the Table-2 and graph below. Among all the compounds tested, SPJ-1g with 2'-chloro substitution at R and SBS1 b with 4'-chloro substitution at $\mathrm{R}$ showed good in-vitro anti-inflammatory activity. The remaining compounds exhibited mild to moderate activity compared to the standard Ibuprofen.

\section{Conclusion}

In conclusion, from the in-vitro anti-inflammatory activity results, it was observed that both electron donating 
and electron withdrawing groups on the aldehydic phenyl ring of the compounds influenced the activity. But aldehydic phenyl ring containing electron withdrawing groups had shown more promising result. Among all the compounds tested, SPJ-1g with 2'-chloro substitution at $\mathrm{R}$ and SPJ-1b with 4'-chloro substitution at $\mathrm{R}$ showed good in-vitro anti-inflammatory activity. The remaining compounds exhibited mild to moderate activities compared to the standard Ibuprofen.

\section{Acknowledgement}

The Authors are thankful to the Management of PES College of Pharmacy for providing all the necessary facilities to carry out the work.

\section{References}

1. Radwan MAA, Fakhr IMI, Seham EB, Omar ME, El-Salam $A$, et al. Synthesis and pharmacological evaluation of 2substituted benzo[b]thiophenes as anti-inflammatory and analgesic agents. Eur J Med Chem. 2009; 44: 1718-25.

2. Singh D, Mohan S, Sharma PC, Sarvanan J. Synthesis and evaluation of some novel piperidino thiophenes as potential antioxidant and anti- inflammatory agents. Acta Pharmaceutica Sciencia. 2007; 49: 29-38.
3. Srinivasa RV, Saravanan J, Mohan S. Synthesis of 2Substituted-amino-3-(N-o-tolylcarboxamido)-4,5-dimethyl thiophenes as analgesic and anti-inflammatory agents. Indian J Hetero Chem. 1998; 8:59-62.

4. Pillai AD, Rathod PD, Xavier FP, Padh H, Sarsanam V, Vasu $\mathrm{KK}$, et al. Tetra substituted thiophenes as anti-inflammatory agents: Exploitation of analogue-based drug design. Bioorg Med Chem Lett. 2005; 13:6685-92.

5. Molvi KI, Vasu BKK, Yerande SG, Sudarsanam V, Haque N. Syntheses of new tetrasubstituted thiophenes novel antiinflammatory agents. Eur J Org Chem. 2007; 42: 1049-58.

6. Gewald K, Schinke E, Bohcher H. 2-Aminothiophenes from methylene-active nitriles, carbonyl compounds and sulfur. Chem Ber. 1966; 99:94-100.

7. Eller GA, Wolfgang Holzer. First synthesis of 3-acetyl-2aminothiophenes using the gewald reaction. Molecules. 2006; 11:371-6.

8. Varm RS, Kumar D. Microwave-accelerated solvent free synthesis of thioketones, thiolactones, thioamides, thionoesters and thioflavonoids. Org Lett. 1999;1(5):697-700.

9. Elias G, Rao MNA. Inhibition of albumin Denaturation and anti-inflammatory activity of dehydrozingerone and its analogs. Ind J Experimental Biology. 1988; 26: 540-42.

10. Hazra K, Sarvanan J, Mohan S. Synthesis and antiinflammatory evaluation of some new thiophene analogs. Asian J Chem. 2007;19(5): 3541-4. 